\title{
'Pants to Poverty'? Making Poverty History, Edinburgh 2005
}

\author{
by Hugo Gorringe and Michael Rosie \\ University of Edinburgh
}

Sociological Research Online, Volume 11, Issue 1,

< http://unw. socresonline.org.uk/11/1/gorringe. $h$ tml>

doi:10.5153/sro. 1261

Received: 4 Oct 2005 Accepted: 16 Mar 2006 Published: 31 Mar 2006

\begin{abstract}
July 2005 saw 225,000 people march through Edinburgh in the city's largest ever demonstration. Their cause was the idealistic injunction to 'Make Poverty History' (MPH). This paper presents an analysis of the MPH march, focusing particularly on the interplay between protestors, the police and the media. Drawing on ongoing research, it interrogates the disjunction between projected and actual outcomes, paying particular scrutiny to media speculation about possible violence. It also asks how MPH differed from previous G8 protests and what occurred on the day itself. The paper considers three key aspects: the composition and objectives of the marchers (who was on the march, why they were there and what they did?), the constituency that the protestors were trying to reach, and the media coverage accorded to the campaign. The intent underlying this threefold focus is an attempt to understand the protestors and what motivated them, but also to raise the question of how 'successful' they were in communicating their message.
\end{abstract}

Keywords: Make Poverty History, Protest, Media, Policing, Social Movements

\section{Introduction}

1.1 In July 2005225,000 people marched through Edinburgh to 'make poverty history'. They aimed to pressure the Group of Eight (G8) leaders to act on debt, trade, climate change and Africa. Months of campaigning meant that the protest eclipsed the 80,000 who gathered in Birmingham in 1998 for the previous UK-based summit, and far exceeded press and police predictions (the local evening paper predicted 'around 120,000', Evening News 01/07/05).

1.2 This paper assesses the Make Poverty History (MPH) march, focusing on the interplay between protestors, police, media and public. The rally proved intriguing for the disparity between prior fears and its carnival atmosphere. We ask why MPH was not the feared catastrophe; why it differed from previous G8 protests; and what occurred on the day itself. We consider two key issues: the who, why, and how of the protestors; and wider (Scottish) public opinion. This dual focus helps to understand the protestors and what motivated them, but also how 'successful' they were in getting their message across. If social movements are understood as attempts to alter public culture (Jasper 1997), then their relation to the wider public is crucial.

\section{Movements \& Global Protest}

2.1 Recent internationally spread protests lead Hubbard \& Miller to describe a 'truly global struggle' against neo-liberalism: G8 summits, 'cannot now take place without the presence of demonstrators' (Hubbard \& Miller 2005: 230). Enthused by innovative tactics and transnational exchanges researchers have tended to view such protests as global phenomena (cf. Stammers \& Eschle 2005), neglecting more localised developments. Morland \& Carter, for example, describe their Anti-Capitalist Britain as 'provocative irony' (2004: 4). Anarchist protest, they argue, is not national but global. As they and fellow contributors point out, however, the increasingly global awareness (and connections) of protestors has not eradicated the nationstate as a meaningful base of social action. Our research, in part, is an attempt to chart the interplay between local, national and global phenomena, to question how far global protest is mediated through local concerns.

2.2 There may be protests at each G8 summit, but whether the same people, tactics and issues are at stake or are mediated by locality is unclear. Whilst protestors may cohere around global issues, alliances 
often depend upon prior bonds established within specific societies (Tarrow \& Della Porta 2005: 241). Protest surrounding the Gleneagles G8 summit, for instance, was dominated by the Make Poverty History (MPH) campaign - an eclectic alliance of NGOs and civil associations, with established British institutions as key actors.

2.3 The loose alliances involved in global protests are variously described as the 'Global Justice Movement' or the 'Movement of Movements'. The common thread is the assertion that social movements engage in deepening the bonds of a global civil society (Mayo 2005, Hubbard \& Miller 2005, Tarrow \& Della Porta 2005). Yet, in tracing the contours of global protest there is little reflection on the phenomenon to be analysed and whether it is a 'movement' or not. Definitional transparency extends beyond nit-picking since action groups have divergent modes of operation, goals and ideals. Stammers \& Eschle (2005: 53) underpin the need for clarity noting that 'most INGOs are economic or technical in character and do not attempt to challenge dominant cultural values' as social movements do.

2.4 Stammers \& Eschle argue that networks embedded in everyday structures of local life should be regarded as part of the global struggle. They emphasise the pivotal importance of 'grassroots activism and non-institutional articulations of collective identity' for social movements (2005: 54). For Plows (2004) local and grassroots networks undertake the bulk of movement action. Whilst large protest events provide spaces for activists to interact and forge common identities and transnational networks, the construction of such commonalities is a process to be investigated rather than assumed. Analysing MPH a priori as an instance of global movement activity obscures the processes that go into movement formation (Melucci 1996).

2.5 Assumptions that global events foster unity and identity are challenged by Stammers \& Eschle, who note the predominance at such protests of 'young, white, rootless, middle-class activists' (2005: 58). They advocate examination of the praxis of grand coalitions and Transnational Social Movement Organisations rather than uncritical acceptance of their pronouncements. Of central concern is whether MPH generated transnational activism - eschewing attempts at centralisation and loosely organised around 'global justice' or whether it conforms to more 'traditional' forms of transnational action, i.e. 'NGO-centred, single-issue policy networks that run organised campaigns based on brokered coalitions' (Della Porta \& Tarrow 2005: 17).

2.6 Plows captures the difference in approach asserting that 'the limits of alliance-based protests (at a local level, at least) for activists are simply that such actions on the whole tend to be 'safe', having networking and the realization of commonly held critiques as the primary end goals' (2004: 105). Unifying diverse groups in coalition requires intensive negotiation and the creation of 'tolerant identities' to accommodate differences (Della Porta \& Tarrow 2005). Emphasis on diversity has replaced equality, glossing over multiple affiliations and conflicting aspirations. Whilst democratisation is a fundamental theme of movement literature, grand coalitions may prioritise campaign goals over internal democratisation (Stammers \& Eschle 2005). The persistent sidelining of voices from the South is but one example of problems that arise as a consequence. Such concerns are to the fore in our analysis of the transformative capacity of MPH.

\section{The Research}

3.1 The paper aims to capture the significance of the MPH demonstration rather than to provide a representative and statistically robust account. We lacked the time and resources to conduct a random survey of protestors and have focused, therefore, on providing a suggestive account that does some justice to opinion about, and experiences of, this event. The research centres around our survey of 524 people on the MPH march itself and an opinion poll carried out by TNS. This data is complemented by participant observation, interviews with senior police officers and protest participants, conversations with dozens of 'ordinary' (often extraordinary) protestors, and a review of newspaper coverage. The opinion poll was conducted before the G8 Summit and focussed on people's perceptions of the demonstrators and anticipation of disruption and violence. Press reports preceded and mediated the MPH event, feeding into peoples' expectations.

\section{Mediating the MPH Message}

4.1 The use of newspaper data in the study of collective action is contentious given serious questions pertaining both to the biases displayed by the media, and the collection practices of social researchers. Despite this, Earl et al. (2004: 77) conclude that newspaper data 'although not without its flaws, ... remains a useful data source'. Such data address one of Melucci's (1996) key concerns by placing an emphasis on action that captures the impetus of social struggle. Furthermore, some of the biases evident in news coverage constitute important data. The significance of the media as a means of mediating a protest group's message to the wider public means that in general, 'if protest tactics are not considered significant by the media ... protest organisations will not succeed. Like a tree falling unheard in the forest, there is no 
4.2 Analysis of media coverage is essential in charting the degree to which a group succeeds in getting its message across. Whilst protestors are rarely regarded as key sources, 'by conforming to the requirements of contemporary news production, even radical activists can sometimes get their alternative analysis and point of view across in the mainstream media' (de Jong et al. 2005: 7). One means of securing media coverage is celebrity endorsement. MPH secured the backing of a swathe of celebrities but this, Timms (2005) explains (and we argue), is not without problems. The centrality of media strategies in influencing the political agenda, shaping public opinion and attracting supporters (cf. De Jong et al. 2005) renders media coverage important data in its own right.

4.3 Given the problems inherent in using media indexing systems (cf. Earl et al 2004) we used daily scans of newspapers for relevant articles. We opted to study local, 'regional' and 'national' papers over a short period rather than focus on a single title following the finding that 'proximity influences selectivity in reporting' (Earl 2004: 74). It became apparent that proximity to the event was correlated with both the extent and nature of coverage. Edinburgh-based papers emphasised the impact of the G8 summit on businesses and road works, whereas national papers tended to take a broader perspective.

4.4 Earl et al (2004) note problematic issues of selection and description. Newspapers report only that they deem to be newsworthy, and they may report in erroneous or misleading terms. We sought to offset the problems of selection with participant observation and interviews to provide alternate perspectives and accounts. Press reports on MPH, however, began well before the event. They constituted the main conduit between protest organisers, police and the general public. Biases of selection and description were in evidence and framed the pre-march context.

\section{Media Premonitions}

5.1 The 'carnival atmosphere' of the MPH march jarred with widely publicised fears for the safety of Edinburgh and its inhabitants. Laudatory media coverage in the immediate aftermath of the rally suggested broad support for the campaign's objectives and universal praise for the participants. Yet there had been no shortage of detractors beforehand, with most newspapers (particularly those with a prominent share of the Scottish market), predicting widespread disruption. Whilst violence at previous G8 events raised concerns it is clear that the selection and description of information was biased towards sensational (and thus 'newsworthy') accounts. Immediately before the march the Scotsman warned 'Scotland battens down the hatches for a G8 storm', noting that 'Court cases have been put off, police leave cancelled and streets cleared of debris to prevent violent protesters using it as missiles' (01/07/05).

5.2 The Scotsman had also reported 'the first rogue campsite' in the city and the fears of a 'packed public meeting'. Another reality was buried within the reportage: 'two tents had appeared' in a city centre park (29/06/05). Concerned residents warned of unruly and uncontrollable protestors camping in front gardens and 'urinating on my doorstep'. That same edition of the Scotsman, more ominously, reported that 'extra beds [were] freed-up for head injury patients' in local hospitals. On the eve of the MPH march, under the headline 'Street of fear: shopping mecca braced for riots' the Daily Record reported that Edinburgh 'was ... bracing itself for G8 bedlam' (01/07/05).

5.3 Such gloomy prognoses began as early as April when the Evening News noted that road works would to be postponed due to the protests (12/04/05), and that McDonalds branches would close 'amid fears of G8 attack' (19/04/05). Yet this latter headline sat above a story in which MPH promised a 'family day out' and police urged Edinburgh to remain 'as open as possible'. Reassurances less readily translate into eyecatching headlines than fearful premonitions. What Earl et al. (2004: 72) refer to as "soft news" (i.e., impressions and inferences of journalists) can be accorded the status of hard news (or fact) through the use of misleading headlines. The Scotsman warned 'that some of the protesters preparing for tomorrow's Make Poverty History march in Edinburgh might be planning to use the occasion for violence'. The press also reported the removal of 'To Let' signs from city properties 'for fear it may advertise an empty house for protesters to squat' (Scotsman 01/07/05; cf. Daily Record 01/07/05). The Evening News claimed 'an army of joiners descended on the city centre to start boarding up shops... to protect against potential attacks' $(01 / 07 / 05)$.

\section{The anarchist World Cup}

6.1 Media coverage assigned a central role to those violent activists expected to infiltrate the 'legitimate' MPH protest. A Daily Record columnist summarised and provoked fears: 'There are plenty hoping to use the $[\mathrm{MPH}]$ jamboree as an excuse to create as much bloody mayhem as they can. The G8 is the anarchists' World Cup, their dream date' (03/06/05). The Herald \& Post (a free paper distributed throughout Edinburgh) oscillated between extremes. In April it reported that petrol stations would be closed, raising 
'fears that the city will grind to a standstill ... with businesses across Edinburgh shut'. Despite reassurances from protest organisers, the paper chose to emphasise that 'protest leaders have admitted there is likely to be a "rogue element" of anarchists' (28/04/05). Later a more optimistic piece urged businesses to stay open and make the most of the many visitors to the city. MPH was a commercial 'opportunity', although readers were reminded that whilst MPH was 'billed as an anti-poverty protest, there are fears it may attract anti-capitalist and anti-globalisation extremists' (12/05/05). The following week the paper argued that protests were "unlikely to lead to trouble", quoting police sources to that effect. Nevertheless, the same article predicted that businesses would pull 'the shutters down rather than risk violent clashes' (19/05/05). With such views - repeatedly emphasising the likelihood of trouble - coming through the door of almost every city home, many awaited the summit with trepidation.

6.2 Both the Scotsman and Evening News anticipated chaos in the 'World Heritage' city. Their tone was frequently sensationalist although stories regularly belied gloomy headlines. In keeping with this approach, the News only presented antithetical voices for its regular 'Your Say' column in April. One reader feared that 'It will be hellish for residents in Edinburgh'; another insisted: 'I won't be going anywhere near the city centre during the protests. I don't want to be trampled by a baying mob' (19/04/05). Recurrent accounts of G8-related violence in Genoa and Seattle reinforced such fears. In sharp contrast there were insistent reassurances from protest organisers and police about the peaceful nature of MPH. The Lothian and Borders Police website carried a link to MPH, and a letter of welcome to protestors from Edinburgh's Lord Provost.

6.3 Anarchists, however, are good copy. Prior to the march the Herald \& Post reported: 'G8 rally fears as anarchists gather in city' (30/06/05). The paper warned that the Dissent network ('a notorious anarchist group responsible for much of the violence during London's May Day riots') planned to "radicalise" the march. Yet none of the quoted radicals mentioned violence, and council and police spokespeople insisted that the MPH march would be peaceful. Abutting the story an NHS public information notice was markedly more upbeat; 'preparing for a Gr8 occasion!' Biases of selection and description coloured much coverage, perhaps most graphically illustrated by the Times'story which "revealed": 'Militant's Secret Plan to Paralyse Scotland' (16/04/05). The report claimed to have 'infiltrated' a meeting of 'hardcore protestors' 'despite the group's obsessive secrecy'. Beneath pictures of past summit violence the Times opined that the 'setting up of a trauma group' indicated that 'G8 anarchists' were preparing for violence. Quotes within the article, however, made it apparent that those in attendance feared police aggression. Such trauma groups are commonplace amongst peaceful demonstrators and the inference drawn by the journalist seemed designed to scare.

6.4 The Times story was taken up by the News under the headline "Extremists in "war summit" to plot G8 protest violence' (16/04/05). This prompted an attendee to write in, pointing out that: 'The camp was in no way secret. It was advertised on the website and in thousands of leaflets we distributed in Glasgow and Edinburgh ... I know of no one on the site who was there to "plot G8 protest violence"' (Evening News 19/04/05). Indeed, as we can attest, anyone following the prospective G8 protests with any diligence would have been aware of the meeting. As one senior police officer told us, the 'press have been ... grossly irresponsible' in their coverage of the anticipated G8 protests, often drawing 'illogical conclusions based on fantasy' since 'good stories' outweighed verification of facts (interview with Cl Ross, 05/06/05).

6.5 Whatever the reality, the media's projection of violent disruption fed into a representation of a petrified city. The Daily Record reported businesses braced for chaos, and quoted one local as saying: 'There will be trouble. I have no doubt about that'. Likewise:

One sharp-suited Bank of Scotland employee, who asked not to be named, said the marches and demos would attract troublemakers from all over Europe. He added: "Eighty per cent of them will be intent on causing problems, in my opinion. It's a worthy cause but I fear Edinburgh will get trashed"'. (01/07/05)

\section{Positive vibrations}

7.1 Positive voices were submerged beneath salacious headlines. The constant stream of sensationalist coverage led one policeman to insist that: 'the press are actively seeking negative comments....There are plenty of more positive accounts, with no fears or negativity, but the press are not interested in this' (Interview with PC White 21/06/05). Throughout our interviews, police frustration was abundant, and with each new 'exclusive':

You feel like: Here we go again! And you have to start the day and address that again and repeat the same assurances that people have heard countless times before, but with each new story people seek more detail and guarantees and it does make my job that much more difficult (ibid.). 
7.2 Police and other bodies wished that more attention was paid to the opportunities that the summit offered and the manner in which it placed Scotland on a world stage. Travel Scotland launched 'the official accommodation, tours and travel booking site for the Make Poverty History (Edinburgh) rally'.

Recommending early booking, they offered tours round Edinburgh and Scotland before joining the protest ${ }^{[1]}$. Other commentators welcomed the march on its own terms rejecting any injunctions to profit from the 'opportunity'. Columnist lain Macwhirter advocated a moral stance:

[T] he capital should be about more than just milking tourists. It should be telling the world that it is open for anyone who wants to come here to make a stand against injustice; that it supports the cause and wants to do all it can to make this a great world event (Sunday Herald 05/06/05).

7.3 Outwith the limelight many reflected this more positive position and looked forward to the march. Churches across the city, and indeed the UK, mobilised for MPH. In one Episcopalian Church, for example, a sermon was given over to an MPH spokesperson, the parish newsletter urged people to join MPH, describing it as "an event for all the family' (St Martin of Tours 2005). Letters pages and comment sites showed that this line of reasoning resonated with many Edinburgh residents, despite the media according more prominence to those fearing the worst.

\section{Opinion Poll evidence}

8.1 Given the systematic privileging of negative voices it is hard to derive a sense of popular perceptions from the media. The questions carried on our behalf by the TNS Scottish Omnibus (a monthly poll comprising 1,100 adults across Scotland) provides an insight into perceptions of the impending events. A majority ( $55 \%$ ) of those questioned agreed (either 'strongly' or 'a little') that hosting the G8 summit would be a 'good thing for Scotland'.

8.2 However, opinion proved more negative regarding the planned demonstrations. When asked whether the protests surrounding the Summit would 'change our world for the better' few were optimistic (See Table 1). Whilst under one third (31\%) agreed that the protests would have a positive impact, over two-fifths $(44 \%)$ felt they would not. Considerably more people strongly disagreed with the view that the protests would produce positive change than strongly agreed ( $19 \%$ as compared to just $5 \%)$.

Table 1. The protests surrounding the G8 summit will change our world for the better

\begin{tabular}{|r|c|}
\hline Strongly agree & $\mathbf{5}$ \\
\hline Agree a little & $\mathbf{2 6}$ \\
\hline Neither agree nor disagree & 22 \\
\hline Disagree a little & $\mathbf{2 5}$ \\
\hline Strongly disagree & $\mathbf{1 9}$ \\
\hline Don't know & 4 \\
\hline
\end{tabular}

8.3 The media foretold severe disruption in Edinburgh and beyond. We asked respondents whether they thought that protests would cause 'major disruption' and whether they were 'likely to be violent' (Tables 2 and 3).

Table 2. The protests will cause major disruption

\begin{tabular}{|r|c|}
\hline Strongly agree & $\mathbf{3 8}$ \\
\hline Agree a little & $\mathbf{3 6}$ \\
\hline Neither agree nor disagree & $\mathbf{1 0}$ \\
\hline Disagree a little & $\mathbf{1 0}$ \\
\hline Strongly disagree & $\mathbf{4}$ \\
\hline Don't know & $\mathbf{2}$ \\
\hline
\end{tabular}

Table 3. The protests are likely to be violent

\begin{tabular}{|r|c|}
\hline Strongly agree & $\mathbf{1 0}$ \\
\hline Agree a little & $\mathbf{3 4}$ \\
\hline Neither agree nor disagree & $\mathbf{1 7}$ \\
\hline Disagree a little & $\mathbf{2 5}$ \\
\hline Strongly disagree & $\mathbf{1 0}$ \\
\hline Don't know & $\mathbf{4}$ \\
\hline
\end{tabular}


There was widespread belief that the G8 protests would cause major disruption, with almost three-quarters of our respondents $(74 \%)$ agreeing that they would. However, the question of likely violence elicited a more divided response, with two fifths $(44 \%)$ agreeing that the protests were likely to be violent compared to around one third $(35 \%)$ disagreeing.

\section{Forward March}

9.1 $\mathrm{MPH}$ was, therefore, perceived as a potential tinderbox in which a just cause might be undermined by violence. MPH was presented as a critical test of policing: Lothian and Borders Police (LBP), we were told, 'have a huge responsibility in setting the tone' for the rest of the Summit (Cl Ross, interview 05/06/05). The LBP website captured the ambiguity of the occasion, noting its global significance whilst alluding to the fear of violence and 'all the wrong reasons':

The police, council and residents of this fine city are hosting an event that will be of significant interest to the world and will set the tone for the G8 summit the following week. Let's ensure that it goes well and puts Edinburgh on the map for all the right reasons. ${ }^{[2]}$

9.2 Given media predictions, one might have expected the atmosphere of the MPH march to have been tense and framed by ranks of police in protective equipment and shuttered shops. The relaxed attitude of the on-duty police officers and marchers appeared to render the media biases transparent. The Meadows the park where the march began and ended - was a sea of stages, marquees and fast food outlets. People milled around with a festive air, added messages to giant boards spelling out 'Make Poverty History', or lazed in the sunshine (see Photo 1). Numbers far exceeded expectations and it soon became clear that people would have to queue for hours to actually march.

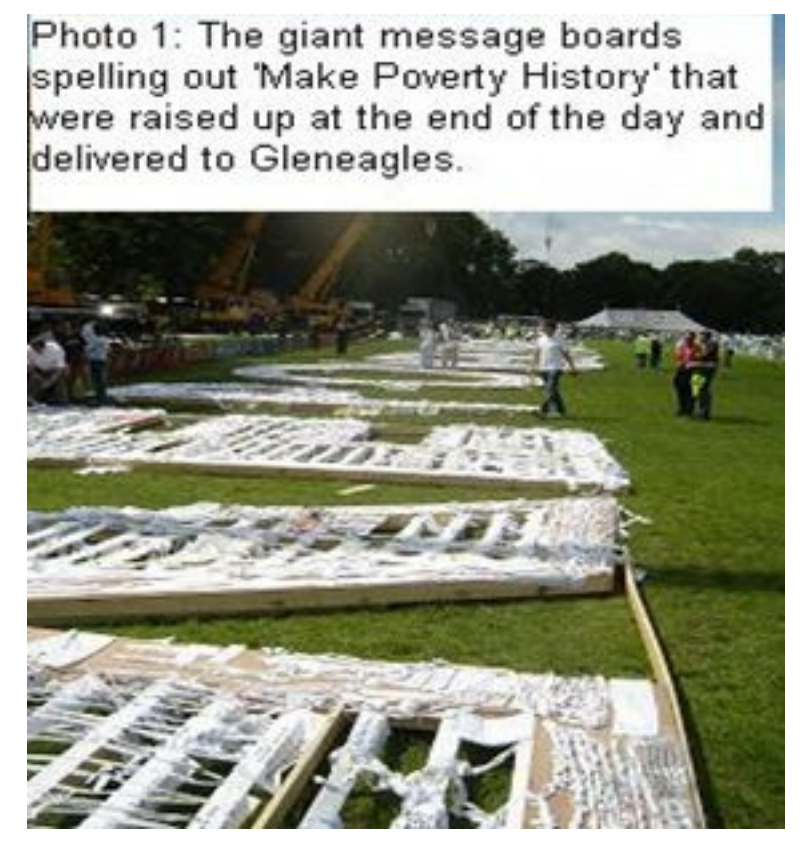

9.3 Protestors rarely mobilise around purely concrete demands and policy objectives. Invariably an 'expressive' dimension seeks to reconfigure social values and identities. Stammers \& Eschle (2005) note the tendency to privilege instrumental demands - casting activists as lobbyists - and downplay the significance of expressive action. Demonstrations, however, inevitably entail symbolic rituals highlighting the cohesion of protestors and communicating their objectives. Gestures and signs are 'condensing symbols' (Turner 1967: 29) which capture and convey the intentions of protestors. MPH voiced concrete demands but relied on heavily symbolic and expressive acts - foremost amongst which was the evocative, expressive invocation to Make Poverty History. White wristbands financed the organisation and participants were asked to wear white clothing to produce a human echo of these bands when the marchers ringed the city centre. Finally, there was a minute's silence to remember those dying in poverty.

9.4 If demonstrations substitute for elections in terms of social movement popularity (Della Porta \& Diani 1999) then MPH scored a clear victory. Several hundred thousand people marched and enjoyed live music and screens broadcasting the international 'Live8' concerts. Policing was friendly, polite and helpful. Officers were in ordinary uniforms, devoid of the 'riot gear' dominating photos of past events in the pre-march media coverage (see Photo 2). Press reports were laudatory. The Sunday Herald devoted 15 pages to MPH and 'Live8'. Its headline proclaimed: '225,000 March to Say One Thing: We Care'. The hitherto pessimistic News carried a 12 page supplement on 'Edinburgh's historic weekend' and praised MPH as a 'text-book case of how to manage a peaceful protest' (Evening News: 04/07/05). 


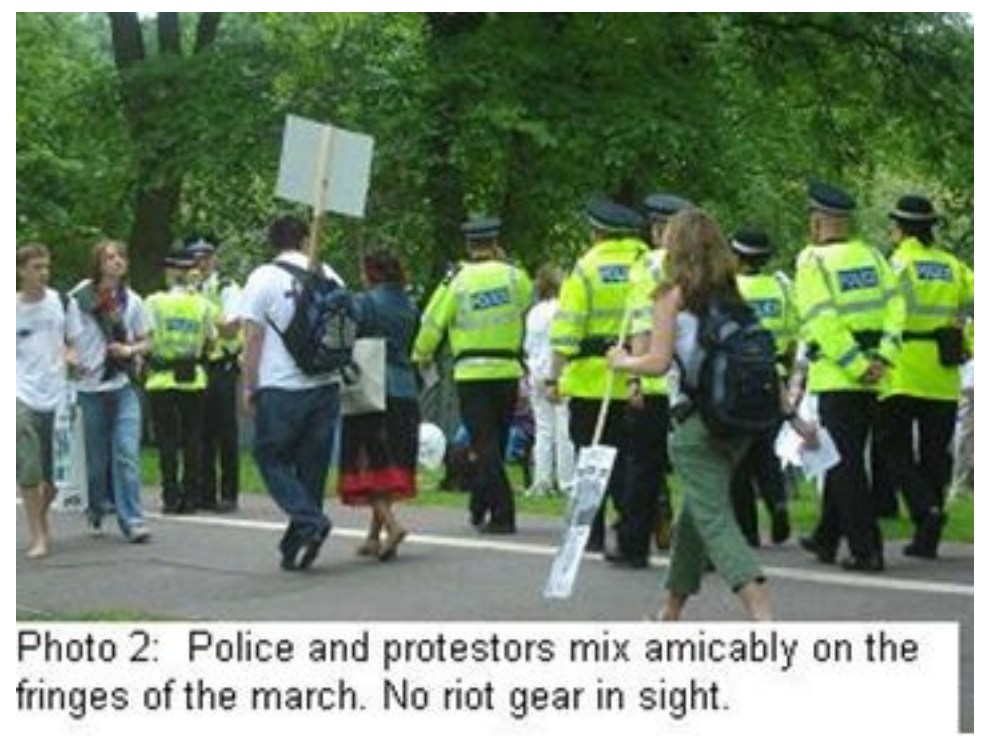

9.5 Earl et al (2004: 72) suggest that hard news is most often subject to omission, but the inferences drawn from an event may be filtered through multiple biases. Not all media attention was so celebratory and the News was not uniformly upbeat, with fears already transferred to upcoming 'anarchist' demonstrations. Police were prepared for 'anything from bank sit-ins to a blockade of burning trucks' (04/07/05). The Sunday Mail described one incident on the fringes of MPH as 'Anarchy in Action', reporting that thugs 'from mainland Europe' attacked police, 'hundreds of innocent passers-by ... caught up in frightening scenes of violence'. Within the story, however, LBP described 'a minor incident ...we are not aware of any arrests and we have to praise in general protestors for their good nature' $(03 / 07 / 05)$. It emerged that sixty "Black Bloc anarchists" were briefly surrounded on the peripheries of the march, but otherwise there was no trouble. Almost one quarter of a million people marched, yet there were no protest-related arrests. As Assistant Chief Constable Dickinson observed:

The biggest public demonstration ever seen in Scotland has just ended with tens of thousands of people expressing their views about world poverty and demanding action. It was a largely peaceful event which took place safely with a mood of camaraderie and a sympathy for the deprived people of the world (Dickinson 02/07/05).

The many shops which remained open conducted business as usual (many with supportive banners in their windows). In the streets leading away from the march people spilled out of cafes, pubs and shops.

9.6 The sunshine, picnics, stages and music meant that the rally resembled a pop concert as much as a protest. This disparity between projected and actual outcomes raises several questions of sociological interest. One line of inquiry obviously pertains to the media and its coverage, but there are also questions about the march itself: Who marched, what did they want, why were police/protestor relations so cordial, and what did the protest achieve? In an interview after the event, ACC Dickinson revealed that there had been serious confrontations on the outskirts of the march where many arrests could have been made but, he argued, the police did not want to tarnish the general mood of the day (Interview 3/10/2005). Apparent here is the capacity for law enforcement authorities to enhance or dampen the presentation of an event. Had the police opted to emphasise disorder, clamp down on 'misbehaviour' and make arrests then media coverage and public opinion would have been swayed in a particular manner. This renders the question of police/protestor relations more pertinent and introduces a specific 'local' factor into the analysis of a 'global' event. Thorough answers to the questions posed above are beyond the remit of this study, but our survey data, observations and interviews offer some insight.

9.7 Our survey of the marchers explored claims that there would be an 'influx' of protestors into Edinburgh. We recorded: Where protestors came from; what they were protesting for (or against); whether they were affiliated to particular organisations; and which protests they intended to participate in. Whilst our survey of 524 marchers was not in any sense a representative or random sample of protestors - a number of researchers were dispersed throughout the marchers with a brief to approach the people around them as and when the march came to a temporary standstill - it does offer a suggestive and indicative snapshot of the variety of people on the protest.

9.8 We had little difficulty in finding local people (see Table 4). Over a third of our respondents lived in Edinburgh itself, with another fifth living elsewhere in lowland Scotland. Overall, a majority of our respondents lived in Scotland. Most of the rest lived in England, notably northern England and London. We were struck by the number of groups who had travelled from across Britain specifically to march before 
9.9 What, though, were they demonstrating for? Several broad patterns of responses emerged: First, many respondents found it difficult to articulate their reasons. Many simply said 'to make poverty history' and references to poverty made up around one-third of responses. Other issues specifically mentioned were fair trade $(15 \%)$ and third-world debt $(12 \%)$. Rather surprisingly, given its prominence on the G8 agenda, very few respondents mentioned climate change or 'the environment' as motivating their protest. This reflects the $\mathrm{MPH}$ focus on debt relief, fairer trade rules and more and better aid, rather than campaigning against the G8 summit as such. The 'tolerant identities' of massive coalitions, it is clear, must be matched by 'acceptable' or 'safe' objectives (cf. Plows 2004).

9.10 The diversity of demonstrators, however, is revealed by the fact that we did not simply get a parroted version of the MPH manifesto. Many individuals had their own reasons for marching and some had more sophisticated political analyses than others. This diversity was captured in a live weblog posted on the morning of the march:

At the moment the figure stands at 120,000 marchers and rising $\ldots$ and it would seem that every person has their own reason for being here. Socialist workers, National Union of Teachers, Christians, Muslims. I even spotted a politician - namely Robin Cook! All here for one reason, to make their voices heard calling to Make Poverty History (Gaunt/Pressureworks 2005).

The march, in other words, was a catch-all affair, but there was a pervasive sense of 'being part of history' and of 'making a difference' (See Photo 3).

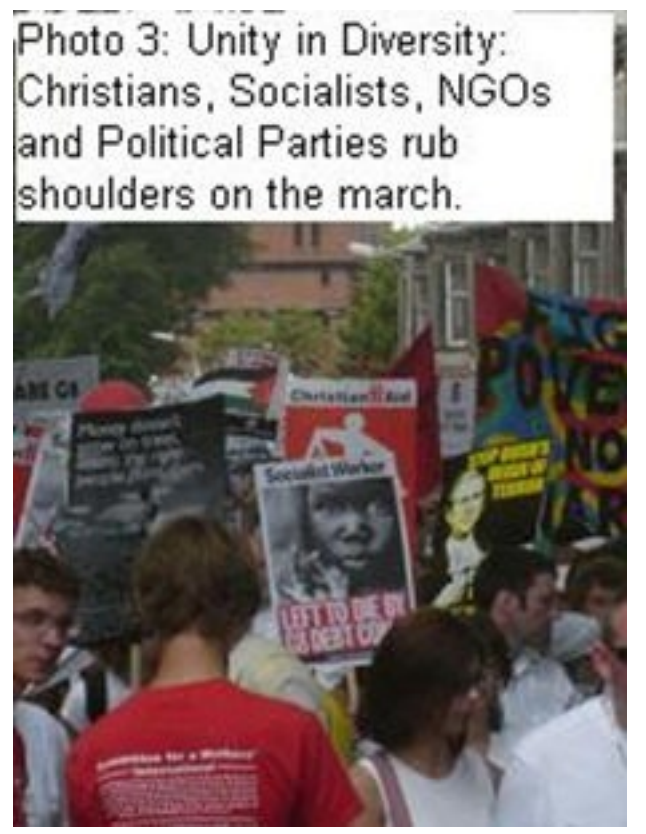

9.11 Moral imperatives were by no means ubiquitous since many respondents reported marching through curiosity or excitement. One Edinburgh man had been initially 'wary of the atmosphere but got caught up in mood and stayed all day'. Other locals insisted that such an event in their city was 'too big to miss'. Despite the sea of organisational banners and placards, relatively few of our respondents $(34 \%)$ claimed to be a member, supporter of, or affiliated (however loosely) to a campaigning or protest organisation. One of the key successes of the MPH, it seems, was its ability to attract non-aligned individuals. The range of organisations named proved exceedingly broad: from Dissent Network to Woodcraft Folk, Clandestine Insurgent Rebel Clown Army to 'sponsoring a child'. Relatively few respondents (about 6\%) named membership of (or support for) a political party, whilst rather more (11\%) claimed some kind of Christian affiliation, mirroring the ubiquity of banners from Christian organisations and parishes.

9.12 Finally, we asked respondents which (if any) other G8-related protests they intended to attend. The intention was to gain an insight into wider commitments to anti-G8 activism. Most respondents, particularly those living outside Edinburgh, had little knowledge about other protests, and we sometimes found ourselves explaining the variety of non-MPH events. Overall, three quarters of our sample intended to attend only MPH. Given that 225,000 attended that protest compared to the 5,000 who demonstrated later at Gleneagles and the smaller attendances at the other protests this proved a clear underestimate.

\section{Discussion}


10.1 How should we understand an event which raised critical issues, galvanised thousands of supporters, brought people of all political hues together and conducted a huge and peaceful rally? Here we draw on social movement theory to provide an analysis of MPH. Most notable is a striking sense of déjà vu. Reading Mayo's (2005) account of 1998's Jubilee 2000 protests in Birmingham the similarities prove abundant. Given that MPH grew out of the former event these resemblances are unsurprising. MPH's main constituents are those which formed the core of Jubilee 2000, their demands are similar and the modus operandi - right down to 'encircling' the city - remained the same. The 1998 coalition Director insisted that 'the world will never be the same again ... because of Jubilee 2000' (Mayo 2005: 172). MPH, however, resembles an inflated version of that campaign, echoing its successes and its drawbacks.

10.2 Despite the optimism accompanying both campaigns, the abiding sense of a replay compels a less sanguine analysis. First, we should consider MPH's achievements. The most apparent triumph was the mobilisation of vast numbers of people. Diverse affiliations were accommodated in the adoption of 'tolerant identities' (Della Porta 2005) - unity in diversity whilst pursuing common goals. A significant aspect of any social movement is its impact on wider society (Rao 1987: 235) and MPH galvanised many who would not normally protest. As our survey data - and the disparity in protest numbers - amply indicate, most marchers had no intention of joining other G8 protests and some had not specifically intended to attend $\mathrm{MPH}$ either.

10.3 The campaign skilfully used media opportunities to reach a wider audience than most protests. Such modes of communication are pivotal in recruiting participants (Kolb 2005). Coverage is most helpful where journalists sympathise with a movement's goals. In adopting broad and uncontroversial aims, MPH won over large sections of the media, in part by reinforcing a distinction between 'good' and 'bad' protestors. MPH spokespeople differentiated between their event and 'rogue anarchist elements'. As more radical G8 campaigners noted: "Already the media is casting "Make Poverty History" as the "good protestors" and Dissent as the "bad"' (Nightwatcher 2005). This enabled news media to focus on common targets. The contested use of celebrity endorsements was also central to media attention

10.4 News media were not the only means of recruitment. In 1998 marketing tools were employed to 'sell' the campaign, and such tactics were heavily utilised in 2005. Short films featuring celebrities helped Make Poverty History become a global 'brand'. Among the most efficacious means of selling the concept were the white wristbands sold to raise money and awareness. Part fashion accessory, part moral statement, the bands became ubiquitous. Minimally, at least, such measures required active involvement - buying the band, wearing it.

10.5 To the extent that supporters became active the attempts at 'conscientization' (Freire 1972) were reinforced. Whilst little effort is involved in wearing a wristband, grass-roots activities by faith organisations, political groups, schools and charities, spread the message in a personalised and accessible manner. Research is needed on the extent to which grassroots activity underpinned, or was inspired by, the MPH campaign. Much local organisation, however, seemed to be fairly institutional. Not only did this encourage sustained participation (as seen in post-march exhortations to keep up the pressure on Governments ${ }^{[3]}$ ) it increased turnout by stressing the family nature of the event - deliberately dissociating it from past violence. The success of this approach to recruitment echoes Bennett's (2005: 225) finding that how people hear about a global justice event is important - those whose only information is the popular media are less likely to participate.

10.6 Active involvement paid dividends as numerous conversations with marchers uncovered a degree of understanding about issues of debt, trade and aid. This reinforces the argument that the MPH campaign was a process of community education (cf. Mayo 2005: 188). The true measure of success in this regard may not be known for some time, but the manner in which the Jubilee 2000 constituency was enlarged, suggests that the process of conscientization has some lasting impact. Those who not only marched but joined organisations are even more likely to sustain their active involvement. Jubilee 2000 comprised 110 organisational members (Mayo 2005), whereas MPH encompasses 500 global institutions (some of whom are themselves coalitions ${ }^{[4]}$ ). The continuity in objectives and participants between 1998 and 2005 is instructive and offers a response to Della Porta's (2005: 200) question about the sustainability of 'tolerant identities'. MPH built on the structures established by Jubilee 2000 and indicates that broad interests can provide the platform for lasting coalitions.

10.7 Any movement consists of heterogeneous social networks (Diani 2003), but coordinating such a multiplicity of groups constitutes a significant achievement. MPH members hail from across the globe, from all faiths and none, and range from student groups to trade unions. Following Stammers \& Eschle (2005), however, it is clear that the essential ingredients of movement activity - grassroots, informal activism - is lacking. There was no scope for individual affiliation and strict boundaries were established to determine which groups could and could not sign up. MPH, therefore, may best be described as a Transnational 
Advocacy Network (TAN), dominated by British based (I)NGOs. Whilst pitched at the global level and focused on a global (G8) summit, we argue that local (at least, national) concerns were hugely significant.

10.8 This brings us back to the participants. Mayo (2005: 191) praised the 'altruism' of Birmingham's marchers. That Edinburgh attracted three times as many testifies both to the impact of MPH and the determination of its supporters but, sidestepping debates about the redundancy of the rational actor model (cf. Jasper 1997: 23-9), it is clear that the altruistic intentions of Edinburgh marchers were more questionable. Ignoring the argument that acting morally can make activists 'feel good', there was the recurrent assertion that marchers wanted to be 'part of history'. The free music, celebrity appearances (with tantalisingly unnamed 'special guests') and exhaustive media coverage encouraged people to respond to their moral consciences. Our intention here is not to belittle, but to problematise.

10.9 Simply dismissing the actions of MPH demonstrators would suggest that 'legitimate' protests - cooperating with police authorities and politicians - are futile. Colin Fox, Scottish Socialist Party convenor, disagrees:

I think everybody who participated in [MPH] will remember it their whole life. You know for lots of reasons: the size, the enormity of it. It was a protest 'protest' at the end of the day. It was a plea for consideration of big, big issues that face the world (Interview 03/08/05).

'After this weekend', one blogger opined, 'enough people will be aware of the issues for the G8 leaders to be always under scrutiny' (Cripps/Pressureworks 2005). Protest movements are certainly central to the dissemination of new perspectives and moral visions (Jasper 1997: 16), but for all MPH's successes, dissenting voices were not hard to find. It is clear that the manner of protest has important ramifications, and the fact that MPH resembled a pressure group rather than a political uprising arguably influenced the campaign's outcomes.

\section{Depoliticising 'Poverty'}

11.1 MPH was the latest in a series of protests designed to put pressure on G8 leaders. Hubbard \& Miller (2005) locate anti-G8 protest firmly within the parameters of the Global Justice Movement. Worldwide protests have led to talk of 'Global Citizens' and an emerging global civil society (e.g. Mayo 2005). The distribution of MPH's members - from the Gambian Horse \& Donkey Trust to the Nepal Leprosy Trust demonstrates the global networks from which protestors emerge. The limited nature of these ties, however, is demonstrated in that whilst MPH marchers may have been thoroughly global in outlook, most were affiliated to, or mobilised by, UK organisations and came from (or lived in) Britain. The absence of Southern voices explicitly raised in relation to 'Live8', was true of MPH and highlighted the democratic deficit evident in many TANs. Most activists, as Tarrow \& MacAdam (2005: 123) found, are not 'rootless cosmopolitans', but embedded social actors.

11.2 The timing and tenor of the campaign lend credence to this finding. It is no surprise that the closest echo of Jubilee 2000 came with the G8's UK return. MPH, in many ways, was a quintessentially 'British' occasion, devoid of the more 'radically politicised' aspects of recent protests elsewhere, and meticulously co-ordinated with police and other authorities. Road signs on routes into Edinburgh carried the council's endorsement for this epitome of consensus politics:

A more polite crowd of demonstrators could not be found! Hundreds of thousands of people are standing in line patiently for hours waiting for their chance to move forward into the streets of Edinburgh to complete the march. Chants, drums, protest songs all happening in a terribly British queue - complete with cups of tea and plates of chips! (Gaunt/Pressureworks).

11.3 The nation-state, as Tarrow \& MacAdam (2005) note, remains the paramount power in global politics, and the rally was deliberately targeted at the summit hosts. The mutually constitutive nature of local and global protest is evident here in that global concerns and political opportunities offered the scope for nationally based protest (cf. Stammers \& Eschle 2005). Part of the impetus behind both protests was that key British politicians were seen as sympathetic. As MPH insisted:

[MPH] brings together a wide range of organisations that share a common belief that urgent action is needed to eliminate world poverty, that the key moment is now, and that the UK government has a crucial role in making this happen (emphasis added) ${ }^{[5]}$

11.4 In keeping with this, Gordon Brown addressed Christian Aid immediately after the march: 'We are today seeing Britain at its best, united as one for a great cause' ${ }^{[6]}$. He promised that protestors would not be disappointed by the summit and deftly associated himself with the MPH campaign. This not only reinforced the national dimension of the rally but raises questions about the diversity of participants. 
11.5 The broad church (literally and metaphorically) approach that attracted so many protestors made for strange bedfellows and depoliticised MPH. It is not simply that some protagonists sit uncomfortably alongside each other, but that their views are intrinsically opposed (Monbiot 2005a). That Bob Geldof and Gordon Brown could jointly adorn the Daily Mail's front page indicates how little a threat to power MPH and 'Live8' posed. This was no anti-establishment demo; rather than pressurising the G8 leaders the rally proved almost a cheerleader for them (cf. Monbiot 2005a). Depoliticisation was at the heart of MPH: whilst Socialists, Greens and radical organisations turned out in force such parties were not allowed to join the coalition. As Colin Fox told us, MPH 'were at pains to say they did not welcome the involvement of political with a small "p" groups in it'. As a consequence of its 'catch-all' appeals, Fox argued, MPH proved politically "pretty pathetic: The idea that [saying] "please" to the G8 leaders was simply going to change the world [...] [was] very naïve, very shallow' (Interview 03/08/05).

11.6 The MPH manifesto raises difficult questions: the simplicity of its three main aims does make them easier to spread. To paraphrase a Jubilee 2000 spokesperson it makes 'poverty a non-technical issue. It's a justice issue' (in Mayo 2005: 179). In disregarding technicalities, however, practicalities are sidelined.

Precisely how poverty is to be tackled without redistribution is unclear, yet the ' $r$ ' word remains absent ${ }^{[7]}$, and the focus on aid, debt and trade - rather than equality, redistribution and justice - resembles charity not solidarity. Paring away difficult questions risks trivialising the issues. The close relationship between MPH and 'Live8' is especially problematic. Swathes of 'protestors' echoed 'pants to poverty' in an unthinking critique of issues demanding a more considered and active response. Devoid of nuanced analysis the moral crusade attacks a 'bad thing'; a unifying concept brushing uncomfortable questions under the carpet. The protest numbers might seem to justify the means, but it is worth considering how broad the appeal actually was.

11.7 We have noted the largely 'British' composition of the rally, but to present this, as Brown does, as a united British front seems unduly optimistic. The sales pitch was appealing (who doesn't want rid of poverty?), but the manner of distribution limited the audience. The 'brand' was not bought into by everyone. One protestor noted: 'everything is branded, white banded - even the homeless guys on the street! We're seeing some of the most ethical tramps in the world here' (Cripps/Pressureworks 2005). Pressures on NGOs to adapt to the market in an ever more competitive sphere - and the pitfalls associated with this have been well documented (Jordan \& Maloney 1997). The sales pitch of MPH was sophisticated reaching out to the 'yoof gener8ion' as well as older justice, charity and faith groups ${ }^{[8]}$ - but the pitch reinforced the demographic of the march. The patronising allusion to "ethical tramps" ignores the fact that homeless magazine, The Big Issue, was a committed supporter (including a white band in its pre-march edition). To some wearing white wristbands, it seems, the poverty to be made history was in far-off places, not on the streets of Edinburgh and the rest of Britain.

\section{Star Struck}

12.1 Relentless branding was reinforced by celebrity sponsors. Even where MPH encouraged people to become active and 'be the star of the show', the appeal to celebrities was explicit:

But it doesn't stop there, we want YOU to be the celebrity in all of this, so forget Robbie Williams, Travis, Eddie Izzard and Natalie Imbruglia and use your imagination to become the hottest thing in pants since Peter Kay! ${ }^{[9]}$

12.2 Whilst the benefits of media coverage explain this approach there are obvious disadvantages. Celebrities may 'campaign' to their own advantage and agenda, deflect attention from issues, and trivialise the movement (cf. Timms 2005). Whilst Jubilee 2000 reined in celebrity supporters and forefronted issues, MPH enjoyed less control. Although Edinburgh was the scene of protest, much media coverage of 'poverty' on Sunday July 3 focused on the 'Live8' concerts. The News of the World, for example, extolled 'The Greatest Show on Earth', highlighting the 'emotional moment' when:

Birhan Woldu, the starving mite seen close to death in famine footage shown at the original Live Aid 20 years ago ... clasped hands with a clearly moved Madonna as the superstar launched into her set (03/07/05).

12.3 This haemorrhaging of coverage from poverty to celebrity was exacerbated when Bob Geldof deviated sharply from the MPH line in calling Gleneagles 'without equivocation the greatest G8 summit there has ever been for Africa' (Red Pepper 2005). To Colin Fox, this underscored the perils of relying on celebrities: 'in the last analysis pop stars are pop stars' (Interview 03/08/05). Being stars, furthermore, they dominate media coverage meaning that Geldof's praise for the summit has overshadowed MPH critiques of the G8 communiqué (cf. Monbiot 2005b). Geldofs optimism (and subsequent silence), raise questions as to whether even 'committed stars' are prepared - or equipped - to put issues above self-image. As one MPH 
insider argued:

Our real demands on trade, aid and debt, and our criticisms of UK government policy in developing countries have been consistently swallowed up by white bands, celebrity luwies and praise upon praise for Blair and Brown (in Hodkinson 2005).

12.4 Hathaway \& Meyer (1997: 67-8) suggest that grand coalitions thrive on 'cooperative differentiation' public assertions of solidarity masking internal differentiation. The director of (MPH affiliated) War on Want broke ranks and demanded a 'more radical response' to the G8. His organisation also affiliated to G8 Alternatives, advocating "democratic alternatives for a better future" (Hilary 2005). Although MPH was mostly a model of co-operative differentiation, this raises questions about the utility of an overly tolerant identity. If 'tolerant identities' are too inclusive they come unstuck. A fundamental difference between movement and coalition activism is that the former depends upon shared identity - a sense of fellow feeling that is stronger than the co-ordination of interests (Stammers \& Eschle 2005)

12.5 Whilst Geldof does not represent MPH he is indelibly associated with it, and his comments compound the idea that MPH was too accommodating. Geldof acted as a broker for MPH, his charisma according legitimacy. Brokers, however, need to carve out neutral spaces for dialogue and enable members to overcome internal conflicts by focusing on common goals (Bandy \& Smith 2005). When common ground is diluted almost beyond recognition and unaccountable 'sponsors' offer divergent perspectives, differences can preclude co-operation. The absence of a meaningful collective identity was further revealed when Hilary (2005) differentiated between MPH and 'protests' - presenting the former as something different; a carnival or government sponsored rally.

12.6 MPH's relationship with the UK government, consensual nature, composition and even venue (40 miles from where $\mathrm{G} 8$ leaders were actually meeting) arguably lessened its political impact. Between the march and the summit the bonhomie established with police evaporated as 'anarchist' demonstrations were met with a 'robust' response. The concerns voiced by Hilary, and the marked difference in policing at subsequent demonstrations, beg the question of whether the sort of pressure exerted by MPH constituents could influence G8 leaders. Monbiot (2005b) highlights the startling disparity between Geldof's approbation of Gleneagles and the rapidity with which G8 leaders reneged on their promises. In its immediate results MPH did not achieve its aims and, as one Department for International Development consultant told us, the concessions agreed were in the pipeline already (Personal Communication). Whilst Germany and Italy sought to evade commitments and the US attempted to tear them up, even Gordon Brown conceded that 'the extra money they [G8 leaders] had promised for aid and the extra money they had promised for debt relief were in fact one and the same' (Monbiot 2005b) In response MPH constituents are adopting a more critical line - but the summit is over and media attention has moved on.

\section{Conclusion}

13.1 MPH attracted protestors far beyond the 'usual suspects', gained a high media profile and reached a huge audience. It conducted the largest rally in Scotland's history in a peaceful and cheerful manner, winning over media critics rather than alienating observers. In terms of political results, the MPH analysis of the deal on aid encapsulates its position: 'While this ... is a step forward, it is far from the historic deal that millions around the world have been demanding'. ${ }^{[10]}$ The faith vested in UK government was not repaid and the issues that gave rise to the campaign are still pressing - witness the Niger famine. Mobilising a symbolic show of force failed to highlight one of the most fatal consequences of poverty. The lack of progress made at Gleneagles highlighted further fractures in the umbrella alliance as Southern activists, such as Jubilee South, adopted a harder line:

The multilateral debt cancellation being proposed is still clearly tied to compliance with conditionalities which exacerbate poverty, open our countries further for exploitation and plunder, and perpetuate the domination of the South. ${ }^{[11]}$

13.2 MPH raised the issue of how global institutions (trade rules for example) can hamper the eradication of poverty, but it did not extend this to a critique of 'the political mechanisms through which the rules of the world are created and revised' (Pogge 2002: 117). As Pogge notes, the hegemony of the nation-state system means that resources and privileges are conferred upon any group constituting 'the government' in a territory even where those governments are dictatorial. The upshot is that new governments are hamstrung by the debts acquired by their predecessors.

13.3 The fragile unity of the coalition has started to fissure revealing the absence of shared identity and the democratic deficit inherent in the coalition structure. Social movements are not just about tangible political results; they are attempts to place issues on the agenda, enable the deprived to demonstrate their power, and contest hegemonic ways of seeing the world (Oommen 1990: 30). MPH should be applauded for its 
mobilisation of the previously un-mobilised (although whether this can be sustained remains to be seen), the forcing of issues onto the agenda and the pressure applied on politicians. Social Movements fuel radical politics, as Giddens notes 'not just because of what they achieve, but because they dramatise what might otherwise go largely unnoticed' (1994: 250). Debt, aid and trade cannot, now, be neglected, but if the sum result is that each summit pays lip service to the issues before reneging on 'commitments', then a different modus operandi is called for. As ActionAid's Southern Africa programme puts it: 'What Africa needed from the G8 was a giant leap forward, all it got was tiny steps ${ }^{\text {[12] }}$. Compromise oriented, consensus based protest has not paid dividends: making poverty history must be more than just a walk in the park:

'We are familiar, through charity appeals, with the assertion that it lies in our hands to save the lives of many or, by doing nothing, to let these people die. We are less familiar with the assertion of a weightier responsibility: that most of us do not merely let people starve but also participate in starving them' (Pogge 2002: 214).

\section{Notes}

${ }^{1}$ http://mph.travelscotworld.co.uk/home/homepage.jsp.

2 http://www.lbp.police.uk/press_release/articles/2005\%5CJune $\% 5 C 30 \% 5$ C $2 . h t m$

${ }^{3}$ Christian Aid News: Autumn 2005: Issue 29

${ }^{4}$ http://www.makepovertyhistory.org/whoweare/members-a.shtml

${ }^{5}$ http://www.bond.org.uk/advocacy/2005/structure.htm

${ }^{6}$ http://news.bbc.co.uk/1/hi/uk/4642053.stm

7 http://www.makepovertyhistory.org/docs/manifesto.doc

${ }^{8}$ http://www.makepovertyhistory.org/gener8ion/index.shtml

${ }^{9}$ http://www.makepovertyhistory.org/gener8ion/index.shtml

$10 \mathrm{http} / / / \mathrm{www} . \mathrm{makepovertyhistory.org/response.shtml}$

11 http://www.jubileesouth.org/upload1/JSstatementforg8.pdf

12 http://www.actionaid.org./index.asp?page_id=491

\section{Acknowledgements}

We are indebted to the University of Edinburgh Development Trust Fund for facilitating our research and to the many volunteers who helped us. We are grateful to Tayside Police, Lothian \& Borders Police, TNS Social, Colin Fox and numerous others, and to Christian Aid for permission to use material from their website. Thanks to Magdalen Gorringe for comments and to the reviewers at Sociological Research Online for constructive insights.

\section{References}

BANDY, J \& SMITH, J (2005) 'Factors Affecting Conflict \& Cooperaton in Transnational Movement Networks', in Bandy \& Smith (eds.): Coalitions Across Borders. Lanham: Rowman \& Littlefield: pp231-52.

BENNETT, L (2005) 'Social Movements beyond Borders', in D.Della Porta and S. Tarrow (eds.): Transnational Protest and Global Activism. Lanham: Rowman \& Littlefield: pp203-226.

DE JONG, W, SHAW, M \& STAMMERS, N (2005): 'Introduction', in DE JONG, W, SHAW, M \& STAMMERS, N (eds.): Global Activism, Global Media. London: Pluto: pp1-14

DELLA PORTA, D and DIANI, M (1999) Social Movements: An Introduction. Oxford: Blackwell 
Politics"', in D.Della Porta and S. Tarrow (eds.): Transnational Protest and Global Activism. Lanham: Rowman \& Littlefield: pp175-202.

DELLA PORTA, D \& TARROW, S (2005): 'Transnational Processes and Social Activism', in D.Della Porta and S. Tarrow (eds.): Transnational Protest and Global Activism. Lanham: Rowman \& Littlefield: pp1-17.

DIANI, M (2003) 'Introduction: Social Movements, Contentious Actions and Social Networks'. In Diani, M and MacAdam, D (ed) Social Movements and Networks: Oxford: Oxford University Press: pp1-18.

EARL, J, MARTIN, A, McCARTHY, J \& SOULE, S (2004) 'The Use of Newspaper Data in the Study of Collective Action', Annual Review of Sociology 30: pp65-80

FREIRE, P (1972) Pedagogy of the Oppressed. Trans: M. Bergman Ramos. London: Sheed and Ward GIDDENS, A (1994) Beyond Left and Right. Cambridge: Polity.

HATHAWAY, W and MEYER, D (1997) 'Competition and cooperation in movement coalitions', in: T. Rochon and D. Meyer (eds.), Coalitions and political movements, Boulder: Lynne Rienner: pp61-79.

HUBBARD, G \& MILLER, D (2005) 'Introduction: Barbarism Inc.' In G. Hubbard \& D. Miller (eds.): Arguments against G8. London: Pluto Press: pp1-15

JASPER, J (1997) The Art of Moral Protest . Chicago: Chicago University Press.

JORDAN, G \& MALONEY, W (1997) The Protest Business. Manchester: M.U.P

KOLB, F (2005) 'The Impact of Transnational Protest on Social Movement Organisations: Mass Media and the Making of ATTAC Germany', in D.Della Porta and S. Tarrow (eds.): Transnational Protest and Global Activism. Lanham: Rowman \& Littlefield: pp95-120.

LIPSKY, M (1968) 'Protest as a Political Resource'. American Political Science Review. 62: pp1144-1158. MAYO, M (2005) Global Citizens: Social Movements and the challenge of Globalization. London: Zed MELUCCI, A (1996) Challenging Codes. Cambridge: CUP

MORLAND, D \& CARTER, J (2004) 'Introduction', in Carter, J \& Morland, D (eds.): Anti-Capitalist Britain. Cheltenham: New Clarion Press: pp1-7

OOMMEN, T (1990) Protest \& Change. Delhi: Sage.

PLOWS, A (2004) 'Activist Networks in the UK', in Carter, J \& Morland, D (eds.): Anti-Capitalist Britain. Cheltenham: New Clarion Press: pp95-113

POGGE, T (2002): World Poverty and Human Rights. Cambridge: Polity.

RAO, M (1987) Social Movements and Social Transformation. Delhi: Ramesh Jain.

STAMMERS, N \& ESCHLE, C (2005): 'Social Movements and Global Activism' in DE JONG, W, SHAW, M \& STAMMERS, N (eds.): Global Activism, Global Media. London: Pluto: pp50-67

TARROW, S \& DELLA PORTA, D (2005) 'Conclusion', in D.DELLA PORTA and S. Tarrow (eds.): Transnational Protest and Global Activism. Lanham: Rowman \& Littlefield: pp227-246.

TARROW, S \& McADAM, D (2005) 'Scale Shift in Transnational Contention', in D.Della Porta and S. Tarrow (eds.): Transnational Protest and Global Activism. Lanham: Rowman \& Littlefield: pp121-147.

TIMMS, D (2005): 'The WDM: Access and Representation of Globalisation' in DE JONG, W, SHAW, M \& STAMMERS, N (eds.): Global Activism, Global Media. London: Pluto: pp125-132

TURNER, V (1967) The Forest of Symbols. Ithaca: Cornell University Press.

\section{Other Sources}

CLOVER/PRESSUREWORKS (2005) 'Campaigner Blogs from the MPH rally'. Saturday July 2, 2005:

10.15am. <http://exchange.pressureworks.org/Members/charlieclover/campaign_update.2005-07-

$02.1785353222>$. 
CRIPPS, J/PRESSUREWORKS (2005): 'Campaigner Blogs from the MPH rally'.

$<$ http://campaignerblogs.typepad.com/makepovertyhistory/>.

DICKINSON, I (2005) 'Press Release', 2 July, 2005:

$<$ http://www.lbp.police.uk/press_release/articles/2005\%5CJuly\%5C02\%5C1.htm>.

GAUNT, R/PRESSUREWORKS (2005) 'Campaigner Blogs from the MPH rally'.

$<$ http://campaignerblogs.typepad.com/makepovertyhistory/>.

HILARY, J (2005) 'Sorry, members only', Red Pepper, June 2005. <http://www.redpepper.org.uk/global/xjun05-hilary.htm>.

HODKINSON, S (2005) 'Make the G8 History', Red Pepper, July 2005.

$<$ http://www.redpepper.org.uk/global/x-jul05-hodkinson.htm>.

MACWHIRTER, I (2005) 'You'll have had your march?' Sunday Herald, $5^{\text {th }}$ June

MONBIOT, G (2005a) 'Africa's New Best Friends', Guardian, $5^{\text {th }}$ June:

<http://www.guardian.co.uk/Columnists/Column/0,,1521411,00.html>.

MONBIOT, G (2005b) 'And still he stays Silent', Guardian, $6^{\text {th }}$ September, 2005:

$<$ http://www.guardian.co.uk/climatechange/story/0,,1563362,00.html>.

NIGHTWATCHER (2005) 'Good and Bad Protestors', <http://listsaktivix.org/pipermail/g8sheffield/2005May/000512.html>.

RED PEPPER (2005) 'In their own words: how campaigners responded to the G8 communique', Red Pepper, July 2005: <http://redpepper.blogs.com/g8/2005/07/in_their_own_wo.html\#more>.

ST MARTIN OF TOURS (2005) News/etter: July/August 2005. 